Fakultas Hukum, Universitas Lampung, Bandar Lampung, Lampung, Indonesia. http://jurnal.fh.unila.ac.id/index.php/corruptio

Volume 2 Issue 2, July - December 2021. PP: 127-136

P-ISSN: 2723-2573 E-ISSN: 2745-9276

\title{
Coordination in the Corruption Eradication Commission (KPK)'s Prosecution Tasks Based on Independence Perspective
}

\author{
Ndaru Satrio, ${ }^{1}$, Nina Zainab ${ }^{2}$ \\ ${ }^{1}$ Universitas Bangka Belitung, Indonesia, satrio.ndaru@gmail.com \\ ${ }^{2}$ Universitas Bhayangkara Jakarta Raya, Indonesia, nina.zainab@ dsn.ubharajaya.ac.id
}

Submitted: Sep 8, 2021; Reviewed: Nov 2, 2021; Accepted: Nov 16, 2021

\section{Article's Information}

Keywords: Coordination; Independence; Prosecution.

DOI:

https://doi.org/10.25041/corruptio.v2i2.2433

\section{Abstract}

Coordination of KPK prosecution duties as stated in Article 12A of Law no. 19 of 2019 amending Law No. 30 of 2002 concerning the Commission for the Eradication of Criminal Acts of Corruption, or Komisi Pemberantasan Korupsi (KPK) raises concerns because it creates dependence on other institutions and certainly reduces the independence of the KPK institution. As for some of the problems that need to be known from the existence of this coordination concept, among others: (1) the coordination can be directed towards the form of KPK's subordination to the prosecutor's institution; (2) coordination makes the confidentiality of data held by the KPK not maintained; (3) this coordination is very prone to conflict of interest with the prosecutor's office; (4) this coordination also raises concerns that rotten politics in the resolution of corruption cases may occur. The author uses independence principle analysis. The type of research used in compiling this paper is normative or doctrinal legal research. The research shows that coordination can be done using clear boundaries. First, coordination is still allowed to the extent that it is possible to combine cases that the KPK may not handle. Second, coordination can also be carried out in the event of merging a corruption case that is not the authority of the KPK. Third, the coordination also can be done in the case of 
the concurrent events. Fourth, the coordination is

only related to procedural law.

\section{A. Introduction}

The Indonesian government introduced new anti-corruption institutional frameworks, including new legislative measures and a powerful specialized body, the Corruption Eradication Commission or Komisi Pemberantasan Korupsi (KPK), as key measures to reduce corruption. The Corruption Eradication Commission is one of the institutions formed with a particular purpose, to be the frontline in eradicating corruption. With the label as a state institution included in the executive clump, this commission is very vulnerable to the tug-of-war between the interests of various parties around it. ${ }^{1}$

The Corruption Eradication Commission has been in charge of all legal proceedings and efforts since the preliminary investigation, full investigation, and prosecution. ${ }^{2}$ Before the establishment of the KPK, there were six national anti-corruption institutions. The State Apparatus Reformation Committee, Operasi Budhi based on Presidential Decree No. 275/1963, TPK in 1968, Committee Four in 1970, the Clean Operation in 1977, and the Anti-Corruption Joint Team in 2000 were established during President Abdurrahman Wahid's tenure. Nonetheless, those institutions were short-lived, owing to the ineffectiveness of their anticorruption efforts. ${ }^{3}$

According to Article 3 of Law No. 19 of 2019 concerning Amendments to Law No. 30 of 2002 Concerning the Corruption Eradication Commission, the Corruption Eradication Commission is a state institution within the executive power clump that is independent and free from the influence of any power in carrying out its duties and authorities. It is sufficient to emphasize that the KPK is a state institution that is independent and unaffected by any power, including the executive. Every state institution must have principles to guide it in carrying out its duties and responsibilities. This is also stated in the regulations governing the KPK. According to Article 5 of Law No. 19 of 2019 concerning Amendments to Law No. 30 of 2002 Concerning the Corruption Eradication Commission, the Corruption Eradication Commission's duties and authorities are based on; legal certainty, openness, accountability, public interest, proportionality, and respect for human rights. The existence of this commission refers to The Independent Commission Against Corruption (ICAC), which the Hong Kong government established in 1974. By nature, the KPK is an independent state institution. The reason is that the KPK is expected to be free from any power in carrying out its duties and authorities. ${ }^{4}$

State institutions entrusted with some executive tasks related to corruption eradication are tasked with difficult and time-consuming tasks. The task is outlined in Article 6 of Law No. 19 of 2019, which amends Law No. 30 of 2002 to include the Corruption Eradication Commission. According to the article, the Corruption Eradication Commission is tasked with carrying out the following tasks:

\footnotetext{
${ }^{1}$ Ahmad Khoirul Umam et al., "Addressing Corruption in Post-Soeharto Indonesia: The Role of the Corruption Eradication Commission," Journal of Contemporary Asia 50, no. 1 (2020): 125-43, https://doi.org/10.1080/00472336.2018.1552983.

2 Ismail and Fakhris Lutfianto Hapsoro, "The Authority of the Corruption Eradication Commission in the Prosecution of Corruption in Indonesia," Journal of Critical Reviews 7, no. 5 (2020): 177-82, https://doi.org/10.31838/jcr.07.05.29.

3 Jin Wook Choi, "Measuring the Performance of an Anticorruption Agency: The Case of the KPK in Indonesia," International Review of Public Administration 16, no. 3 (2011): 45-63, https://doi.org/10.1080/12294659.2011.10805207.

4 Ndaru Satrio and Sintong Arion Hutapea, "Reformulasi Rekrutmen Penyelidik Dan Penyidik Komisi Pemberantasan Korupsi Perspektif Cita Hukum Pancasila,” Res Judicata 4, no. 2 (2021): 186-99.
} 
1. Preventive measures are taken to ensure that corruption does not occur.

2. Coordination with agencies authorized to carry out the Eradication of Corruption Crimes and agencies responsible for providing public services.

3. Keep an eye on how the state government is being carried out.

4. Supervision of the agency tasked with eradicating criminal acts of corruption.

5. Corruption crimes are investigated, advanced investigated, and prosecuted.

6. Actions to carry out judicial decisions and court decisions with long-term legal ramifications.

The coordination function is undeniable and must be performed by all KPK elements. According to Article 8 letter (a) of Law No. 19 of 2019 concerning Amendments to Law No. 30 of 2002 Concerning the Corruption Eradication Commission, the Corruption Eradication Commission has the authority to: coordinate investigations, advance investigations, and prosecutions in the Eradication of Corruption Crimes.

Indonesian legislators adopted elements from other anti-corruption agencies, but always with the Indonesian context in mind, and designed the blueprint for a mighty anti-corruption agency with a broad mandate in prevention and enforcement. According to article 11 of the KPK Law, the KPK has the authority to investigate and prosecute cases involving law enforcement personnel or public officials, causing particular public concern, and/or resulting in losses to the state budget of at least Rp. 1 billion (approximately \$US 116000 ). ${ }^{5}$ In addition to the article's provision, the author finds it again in Article 12A of Law No. 19 of 2019 concerning Amendments to Law No. 30 of 2002 concerning the Corruption Eradication Commission. The article states that: In carrying out the prosecution task as referred to in Article 6 letter e, the prosecutor at the Corruption Eradication Commission shall coordinate in accordance with the provisions of the legislation.

Even though it does not cover all of the steps in the criminal justice system, Article 21 of the Law on Corruption Eradication can still be used to assist law enforcement agencies in applying the law in corruption cases. The strength of this article lies in its breadth, as it does not explicitly mention the term obstruction of justice. With such legal pliability, any action that, in the opinion of law enforcement officers, obstructs an investigation can be prosecuted as an act of obstruction of justice. ${ }^{6}$ The existence of a coordination function that is embedded in several provisions, according to the author, makes it difficult for the KPK to carry out its duties. It will even interfere with the institution's independence, especially when we look at the reasons for its emergence, which started from distrust of the police and the prosecutor's office, in which the KPK had to coordinate with these two institutions.

Such a situation provoked the author to provide an analysis. The analytical tool used by the author is a relevant theory or principle that can be used as a guide to dissecting the problems faced. The theory or principle will also be used to find the right solution to the problems that occur. The author chooses independence as his analytical knife.

Based on the foregoing, the author is eager to discuss this subject. The problem is stated as follows: What is the issue with coordinating the prosecution of the KPK in Article 12A of Law No. 19 of 2019 concerning Amendments to Law No. 30 of 2002 Concerning the Corruption Eradication Commission from an independent standpoint? And how has the coordination of the KPK's prosecution duties changed since its independence? The type of research used in compiling this paper is normative or doctrinal legal research. Normative legal research prioritizes library research. In the study of normative law, the law is seen as a norm, whether it

\footnotetext{
${ }^{5}$ Sofie Arjon Schutte, "From Global Paradigms to Grounded Policies: Local Socio-Cognitive Constructions of International Development Policies and Implications for Development Management," Journal Public Administration and Development 32, no. April (2012): 38-48, https://doi.org/10.1002/pad.

${ }^{6}$ Saldi Isra et al., "Obstruction of Justice in the Effort to Eradicate Corruption in Indonesia," International Journal of Law, Crime and Justice 51 (2017): 72-83, https://doi.org/10.1016/j.ijlcj.2017.07.001.
} 
is positive (ius constitutum) or not yet positive (ius constituendum). ${ }^{7}$ Therefore, in normative legal research, the data source is only secondary data, consisting of primary legal materials, secondary legal materials and tertiary legal materials. ${ }^{8}$ Secondary legal materials are used to help understand various legal concepts in primary legal materials. Analysis of primary legal materials is assisted by secondary legal materials obtained from various sources, including journals, books, papers, and other scientific works. A literature study does the data collection technique. The approach used is a statutory approach, which is research that prioritizes legal materials in the form of laws and regulations as primary reference material in conducting research.

\section{B. Discussion}

1. The Problem with Coordinating the Prosecution of the KPK in Article 12A of Law No. 19 of 2019 Concerning Amendments to Law No. 30 of 2002 Concerning the Corruption Eradication Commission from an Independent Perspective

According to Article 3 of Law No. 19 of 2019 concerning Amendments to Law No. 30 of 2002 Concerning the Corruption Eradication Commission, the Corruption Eradication Commission is a state institution within the executive power clump that is independent and free from the influence of any power in carrying out its duties and authorities. The above provisions are sufficient to confirm that the Corruption Eradication Commission or Komisi Pemberantasan Korupsi (KPK) is an independent state institution and is free from any influence of power, including even the executive. The birth of independent state institutions is the transition of the power functions inherent in the legislative, executive and judicial institutions to become independent functions of separate organs. Therefore, often these independent state institutions carry out diverse functions, and each is independent. ${ }^{9}$

Independent in English is written independently, not governed by another, not requiring or relying on something or somebody else, not easily influenced. Black's Law Dictionary mentions independent as not dependent; not subject to control, restriction, modification, or limitation from a given outside source. ${ }^{10}$ Characteristics of state institutions that can be said as independent state institutions are as follows:

a. The formed and determined institutions do not become part of the existing branches of power. At the same time, they become institutions that carry out tasks that the government previously held.

b. The election process is through selection and does not involve political power.

c. The selection and dismissal process can only be carried out based on the underlying rules.

d. In holding power as an instrument of the state, the deliberation process is solid. Reporting is brought closer to the people, either directly or indirectly, through representatives of the people in parliament.

e. Leadership is a collegial and collective decision-making process in performing their duties and functions.

f. Not a nation-state primary that its absence leads the country impossible to walk. Still, its presence is significant because of the demand period of transition, and the needs of the state administration are increasingly complex.

\footnotetext{
${ }^{7}$ Soetandyo Wignjosoebroto, dalam Derita Prapti Rahayu, "Delik Izin Lingkungan Yang Terabaikan," Jurnal Yudisial 8, no. 2 (2015): 217.

${ }^{8}$ Derita Prapti Rahayu, Metode Penelitian Hukum (Yogyakarta: Thafa Media, 2020): 8.

${ }^{9}$ Sekar Anggun Gading Pinilih, "Politik Hukum Kedudukan Kpk Sebagai Lembaga Pemberantasan Korupsi Di Indonesia,” Jurnal Hukum Progresif 8, no. 1 (2020): 23, https://doi.org/10.14710/hp.8.1.15-27.

${ }^{10}$ Arliman dalam Andrew Shandy Utama, "Independensi Pengawasan Terhadap Bank Badan Usaha Milik Negara (Bumn) Dalam Sistem Hukum Nasional Di Indonesia,” Soumatera Law Review 1, no. 1 (2018): 10, https://doi.org/10.22216/soumlaw.v1i1.3312.
} 
g. Has the authority to issue its own rules that can apply to the public.

h. Has a basis of legitimacy in both the constitution and laws. ${ }^{11}$

Independent is the nature of freedom, and it is absolute in the sense that it does not take sides with any party other than those inherent in that nature. Every legal state must have a judicial institution that is free and impartial to everyone. Provisions for judicial institution independence in Indonesia are included in Article 24 paragraph (1) of the 1945 Constitution because independence is essential for the rule of law. The position of the KPK is equated with state institutions, as stated in the 1945 Constitution. Therefore, the KPK also has an independent nature. The KPK as a commission must also be carefully understood as an institution not interfered with in its affairs. William F. Fox also argued that a state commission is independent if expressly stated in the law on the commission concerned, made by Congress. This is so that the president cannot freely decide (discretionary decision) the dismissal of the head of the state commission. The existence of this independent state commission is justified by the complexity of regulating certain matters and tasks that are supervisory and require particular expertise. ${ }^{12}$

Demands to the eradication of corruption have been carried out since the days of President Soeharto until today. Every leader promised during their reign to eradicate and eliminate corruption. In reality, corruption persists and thrives as if the law is powerless to stop it. ${ }^{13}$ Rampant criminal acts of corruption are a form of resistance to the law, which is carried out by some communities or a small number of specific community members who take refuge in power or authority for their interests by harming state finances. ${ }^{14}$ According to the explanation of the KPK Law, it states that the role of the KPK is as a trigger mechanism, which means encouraging or as a stimulus so that efforts to eradicate corruption by existing institutions become more effective and efficient. In addition to the role played by the KPK, the duties of the KPK are: coordinating with agencies authorized to eradicate corruption; supervision of the agency authorized to eradicate corruption; conducting investigations, advance investigations, and prosecutions of corruption; taking steps to prevent corruption, and monitor the implementation of state government. ${ }^{15}$

The KPK must coordinate in carrying out its prosecution duties as stated in Article $12 \mathrm{~A}$ of Law No. 19 of 2019 concerning Amendments to Law No. 30 of 2002 concerning the Corruption Eradication Commission. The coordination in this article also raises concerns in the mind of the author. There are several reasons as well as problems behind the concerns regarding the independence of this KPK institution.

First, the reason is apparent: coordination can be directed towards a form of KPK's subordination to the prosecutor's office. If this happens, then the position of the KPK seems to be under the prosecutor's office. Although it is clearly stated in Article 6 letter d of Law No. 19 of 2019 concerning Amendments to Law No. 30 of 2002 concerning the Corruption Eradication Commission, KPK supervises the institutions authorized to carry out the Corruption Eradication Commission, but this opens up opportunities for the KPK to be under the control of other

11 Neny Fathiyatul Hikmah, "Keberadaan Dewan Pengawas Terhadap Independensi Komisi Pemberantasan Korupsi Perspektif Siyasah Dusturiyah,” Al-Balad: Journal of Constitutional Law 2, no. 2 (2020): 17.

12 Zainal Arifin Mochtar dalam Esmi Warasih, "Wewenang Komisi Pemberantasan Korupsi Dalam Penghentian Penyidikan Dan Penuntutan Perspektif Independensi,” University of Bengkulu Law Journal 5, no. 1 (2020): 41.

13 Oksidelfa Yanto, "Efektifitas Putusan Pemidanaan Maksimal Bagi Pelaku Tindak Pidana Korupsi Dalam Rangka Pengentasan Kemiskinan," Syiah Kuala Law Journal 1, no. 2 (2017): 18-36, https://doi.org/10.24815/sklj.v1i2.8471.

${ }^{14}$ Ismail Prabowo, Memerangi Korupsi Dengan Pendekatan Sosiologis (Surabaya: Dharma Wangsa Media Press, 1998): 26.

${ }^{15}$ Kartika Sasi Wahyuningrum, Hari Sutra Disemadi, and Nyoman Serikat Putra Jaya, "Independensi Komisi Pemberantasan Korupsi: Benarkah Ada?," Refleksi Hukum: Jurnal Ilmu Hukum 4, no. 2 (2020): 250, https://doi.org/10.24246/jrh.2020.v4.i2.p239-258. 
institutions. This undermines the independence of the KPK. Based on this supervisory task, the KPK has the authority regulated in Article 8; namely, the KPK can conduct supervision, research or review of agencies that carry out their duties and authorities related to eradicating corruption and agencies that carry out public services. In carrying out this authority, the KPK is also authorized to take over the advance investigation or prosecution of perpetrators of corruption crimes carried out by the police or the prosecutor's office. ${ }^{16}$

Second, this coordination will make the confidentiality of the data held by the KPK not be maintained again because other institutions also know about it. This coordination concept provides information space for other institutions related to handling a case. The initial data owned by the KPK, whether they like it or not, must be informed to the relevant institutions. It will be perilous if the data is not able to be maintained. It is even more dangerous if this can create an opening for legal subjects who are KPK targets to prepare themselves or even run away from being chased by the KPK. The author still remembers clearly when the suspect Harun Masiku has yet to be identified his location. Again, the independence of the KPK regarding information is no longer maintained.

Third, this coordination is vulnerable to conflicts of interest with related institutions, especially the prosecutor's office. When there are different understandings regarding objects or even legal subjects related to corruption cases, it is feared that it will lead to conflicts between institutions. A fatal thing can have implications for the settlement of a corruption case hampered by this conflict. Sectoral ego in an institution must always exist. If you are unable to contain the sectoral ego, problems will arise. In resolving criminal acts of corruption, it requires coordination between law enforcers, especially the Corruption Eradication Commission (KPK), the Police and the Prosecutor's Office. At present, there is still no good cooperation or coordination relationship in carrying out the eradication of criminal acts of corruption and even competing for roles in uncovering corruption cases. ${ }^{17}$

Fourth, this coordination also raises concerns about rotten politics in resolving corruption cases. For example, the KPK will undoubtedly be reluctant to act if the legal subject they are targeting is an institution coordinating with the KPK. In this case, the agency is the prosecutor's office. Selective cutting in the resolution of corruption cases will undoubtedly occur if the concept is like this. For the umpteenth time, institutional independence has been hindered by cross-border coordination.

\section{The Meaning of Coordination of KPK's Prosecution Task Independence Perspective}

Corruption is a threat to the ideals of a just and prosperous society. ${ }^{18}$ Corruption has become a serious issue that affects people all around the world. Corruption is regarded as an extraordinary crime that jeopardises state security and society's well-being. Corruptors are referred to as white-collar criminals because they frequently utilise their authority and position for personal gain. The procedures are incredibly well-organised, from implementation to the quantity of state money that is corrupted. ${ }^{19}$ Nowadays, eradicating corruption is not a local agenda but an

\footnotetext{
${ }^{16}$ Hibnu Nugroho, "Efektivitas Fungsi Koordinasi Dan Supervisi Dalam Penyidikan Tindak Pidana Korupsi Oleh Komisi Pemberantasan Korupsi,” Jurnal Dinamika Hukum 13, no. 3 (September 2013): 392-401.

${ }^{17}$ Handoko dalam Ni Putu Gita Loka Chindiyana Dewi, I Nyoman Sujana, and Luh Putu Suryani, "Koordinasi Wewenang Komisi Pemberantasan Korupsi (KPK) Dengan Penegak Hukum Lainnya Dalam Melakukan Penyidikan Tindak Pidana Korupsi," Jurnal Preferensi Hukum 2, no. 1 (2021): 122, https://doi.org/10.22225/jph.2.1.3056.119-124.

18 Andi Hamzah, Korupsi Di Indonesia Masalah Dan Pemecahannya. (Jakarta: Gramedia Pustaka Utama, 1991): 2.

${ }^{19}$ Ni Putu Riska Chandra Dewi, Diah Ratna Sari Hariyanto, and Anak Agung Ngurah Wirasila, "Kebijakan Pidana Mati Terhadap Pelaku Tindak Pidana Korupsi Dalam Perspektif Undang-Undang Pemberantasan Tindak Pidana Korupsi," Jurnal Kertha Wicara 10, no. 2 (2021): 174-84.
} 
international agenda in various countries. ${ }^{20}$ This shows how dangerous corruption is for all countries. Corruption has become a disease that is slowly emerging as a scourge that can destroy the country's economy. If corruption in a society is rampant and becomes an ordinary thing for the people every day, the result will be that the society becomes a chaotic society. There is no social system that can work properly. ${ }^{21}$

According to legal logic, the concept of coordination should remain within the corridor that we can accept. This means that this coordination can be done using clear boundaries. The limitations in question are; first, coordination is still allowed to the extent that it is possible to combine cases that the KPK may not handle. Second, coordination can also be carried out in the event of merging a corruption case that is not the authority of the Corruption Eradication Commission or Komisi Pemberantasan Korupsi (KPK). Third, the coordination also can be done in the case of the possibility of concurrent events. This combination can be in the form of concursus idealis, consursus realis, and voorgezette handeling. In this case, it is possible that the KPK only handles or has authority over some cases.

What is meant by concurrently is the occurrence of two or more criminal acts by one person. The crime committed for the first time has not been sentenced to a crime, or between the initial crime and the subsequent crime has not been limited by a judge's decision. The provisions regarding concurrent are correlated to resolving cases and imposing penalties if there is more than one not examined crime. ${ }^{22}$ Concurrently committing a crime or what is commonly referred to as (concursus) is regulated in the Criminal Code. Concursus is a person with one or more acts resulting in several criminal regulations being violated. Concursus never experience judge's decision, and the judge's decision on a criminal act committed by a person will coincide at the same time as other actions the judge will decide at the same time. ${ }^{23}$ The article regulates starts from Article 63 to Article 71 of Book I, Chapter VI of the Criminal Code. From some of these articles, we can understand that many people's views are wrong. So far, some people think that someone who commits a combination of several criminal acts will get a punishment that is doubled according to the actions he has committed.

Theoretically, the concursus is known in 3 (three) forms as stated by Teguh Prasetyo, namely: (1) concursus idialis (Article 63 of the Criminal Code); (2) the act continues (Article 64 of the Criminal Code); (3) concursus realis (Article 65 of the Criminal Code). ${ }^{24}$ Stated, Satochid Kartanegara explained that Concursus Idealis / Eendaadse Samenloop exists when someone commits an act and by doing that one act, violates several criminal law regulations. Thus he commits several offences. VOS defines realis concursus occurs in terms of facts that must be viewed as separate acts, and each of them is a crime, committed by someone and between the time of occurrence of each fact it is not / has not been decided a crime against one of them. The facts do not need to be of the same kind, and there is no need for a relationship between them. This continuous action is referred to as "Continuous Action", meaning that

\footnotetext{
${ }^{20}$ Jovial Falah Parama and Sholahuddin Al-Fatih, "Kajian Yuridis Ambivalensi Pergeseran Independensi Komisi Pemberantasan Korupsi (Kpk) Ke Dalam Rumpun Lembaga Eksekutif," Journal Komunitas Yustisia Universitas Pendidikan Ganesha Program Studi Ilmu Hukum 4, no. 1 (2021): 58.

21 Wicipto Setiadi, "Korupsi Di Indonesia (Penyebab, Bahaya, Hambatan, Dan Upaya Pemberantasan, Serta Regulasi"," Jurnal Legislasi Indonesia 15, no. 3 (2018): 249-62.

22 Prisilia Anggraini Evelyn Terisno and Yuliana Angela, "Penjatuhan Dua Putusan Perkara Pidana Dalam Suatu Objek Perkara Yang Sama (Kajian Putusan Nomor 2135 K/Pid.Sus/2016),” Indonesian Journal of Criminal Law (IJoCL) 1, no. 1 (2019): 105-37, https://doi.org/10.31960/ijocl.v1i1.145.

${ }^{23}$ Sy. Yusriadi, Suhadi, and Rosdiana, "Analisis Hukum Terhadap Penegakan Hukum Perbarengan Antara Tindak Pidana Penggelapan Dengan Tindak Pidana Narkotika Di Kota Balikpapan,” Lex Suprema 2, no. 1 (2020): 131.

24 Fahrurrozi Fahrurrozi and Abdul Rahman Salman Paris, "Tinjauan Tentang Sistem Pemidanaan Dalam Perbarengan Tindak Pidana Menurut Kuhp," Media Keadilan: Jurnal Ilmu Hukum 9, no. 2 (2019): 124, https://doi.org/10.31764/jmk.v9i2.889.
} 
continuous action exists when several actions are related, so that it must be viewed as an ongoing action. ${ }^{25}$

The essence of the author's analysis is that, in principle, this coordination can still be carried out as long as it does not fall into the realm of the substance of the case. The coordination in question is only related to procedural law. This is directly related to the evidence in settlement of a corruption case that is being carried out. The application or enforcement of the public criminal law is carried out by instruments authorized by law to carry out their respective authorities and powers and must be carried out in a systematic effort to achieve its objectives. This systematic effort is carried out by using all the elements involved as a whole and interconnected (interrelation) and mutually influencing each other. ${ }^{26}$

\section{Conclusion}

Coordination of KPK prosecution duties as stated in Article 12A of Law No. 19 of 2019 concerning Amendments to Law No. 30 of 2002 concerning the Corruption Eradication Commission (KPK) raises its concerns because it creates dependence on other institutions and certainly reduces the independence and independence of the KPK institution. As for some of the problems that need to be known from the existence of this coordination concept, among others: (1) the coordination can be directed towards the form of KPK's subordination to the prosecutor's institution; (2) coordination makes the confidentiality of data held by the KPK not maintained; (3) this coordination is very vulnerable to conflict of interest with the prosecutor's office; (4) this coordination also raises concerns that rotten politics in the resolution of corruption cases may occur.

According to legal logic, the concept of coordination should remain within the corridor that we can accept. This means that this coordination may be carried out using clear boundaries so that the independence of the KPK can be maintained. The limitations in question are; first, coordination is still allowed to the extent that it is possible to combine cases that the KPK may not handle. Second, coordination can also be carried out in the event of merging a corruption case that is not the authority of the KPK. Third, the coordination also can be done in the case of the possibility of concurrent events. Coordination in principle can still be carried out if it does not fall into the realm of the substance of the case. The coordination in question is only related to procedural law. This is related to the evidence in settlement of a corruption case that is being carried out.

\section{Acknowledgements}

Praise and gratitude for God Almighty's presence for His blessings and mercy, the author, can complete this research. On this occasion, the authors express their gratitude for the support that has been given in doing research. We want to thank:

1. Hibnu Nugroho, as one of the mentors in the many studies we have done;

2. Hotma P. Sibuea, as one of the mentors in the many studies we have done;

3. Our family, who always provides support and prayers in every activity we do.

\footnotetext{
${ }^{25}$ I Ketut Rai Setiabudhi, Buku Ajar Hukum Pidana Lanjutan (Denpasar: FH Udayana, 2016): 85-88.

26 Abdul Azis, "Kewenangan Komisi Pemberantasan Korupsi Dalam Pemberantasan Tindak Pidana Korupsi Berdasarkan Teori Negara Hukum," Jurnal Surya Kencana Satu : Dinamika Masalah Hukum Dan Keadilan 9, no. 2 (2019): 82, https://doi.org/10.32493/jdmhkdmhk.v9i2.2286.
} 


\section{Bibliography}

\section{A. Books}

Hamzah, Andi. Korupsi Di Indonesia Masalah Dan Pemecahannya. Jakarta: Gramedia Pustaka Utama, 1991.

Prabowo, Ismail. Memerangi Korupsi Dengan Pendekatan Sosiologis. Surabaya: Dharma Wangsa Media Press, 1998.

Rahayu, Derita Prapti. "Delik Izin Lingkungan Yang Terabaikan.” Jurnal Yudisial 8, no. 2 (2015): 217.

- Metode Penelitian Hukum. Yogyakarta: Thafa Media, 2020.

Setiabudhi, I Ketut Rai. Buku Ajar Hukum Pidana Lanjutan. Denpasar: FH Udayana, 2016.

\section{B. Journals}

Azis, Abdul. "Kewenangan Komisi Pemberantasan Korupsi Dalam Pemberantasan Tindak Pidana Korupsi Berdasarkan Teori Negara Hukum." Jurnal Surya Kencana Satu: Dinamika Masalah Hukum Dan Keadilan 9, no. 2 (2019): 82. https://doi.org/10.32493/jdmhkdmhk.v9i2.2286.

Choi, Jin Wook. "Measuring the Performance of an Anticorruption Agency: The Case of the KPK in Indonesia." International Review of Public Administration 16, no. 3 (2011): 4563. https://doi.org/10.1080/12294659.2011.10805207.

Dewi, Ni Putu Riska Chandra, Diah Ratna Sari Hariyanto, and Anak Agung Ngurah Wirasila. "Kebijakan Pidana Mati Terhadap Pelaku Tindak Pidana Korupsi Dalam Perspektif Undang-Undang Pemberantasan Tindak Pidana Korupsi.” Jurnal Kertha Wicara 10, no. 2 (2021): 174-84.

Fahrurrozi, Fahrurrozi, and Abdul Rahman Salman Paris. "Tinjauan Tentang Sistem Pemidanaan Dalam Perbarengan Tindak Pidana Menurut Kuhp." Media Keadilan: Jurnal Ilmu Hukum 9, no. 2 (2019): 124. https://doi.org/10.31764/jmk.v9i2.889.

Falah Parama, Jovial, and Sholahuddin Al-Fatih. "Kajian Yuridis Ambivalensi Pergeseran Independensi Komisi Pemberantasan Korupsi (Kpk) Ke Dalam Rumpun Lembaga Eksekutif." Journal Komunitas Yustisia Universitas Pendidikan Ganesha Program Studi Ilmu Hukum 4, no. 1 (2021): 58.

Hikmah, Neny Fathiyatul. "Keberadaan Dewan Pengawas Terhadap Independensi Komisi Pemberantasan Korupsi Perspektif Siyasah Dusturiyah." Al-Balad: Journal of Constitutional Law 2, no. 2 (2020): 17.

Ismail, and Fakhris Lutfianto Hapsoro. "The Authority of the Corruption Eradication Commission in the Prosecution of Corruption in Indonesia." Journal of Critical Reviews 7, no. 5 (2020): 177-82. https://doi.org/10.31838/jcr.07.05.29.

Isra, Saldi, Yuliandri, Feri Amsari, and Hilaire Tegnan. "Obstruction of Justice in the Effort to Eradicate Corruption in Indonesia." International Journal of Law, Crime and Justice 51 (2017): 72-83. https://doi.org/10.1016/j.ijlcj.2017.07.001.

Ni Putu Gita Loka Chindiyana Dewi, I Nyoman Sujana, and Luh Putu Suryani. "Koordinasi Wewenang Komisi Pemberantasan Korupsi (KPK) Dengan Penegak Hukum Lainnya Dalam Melakukan Penyidikan Tindak Pidana Korupsi." Jurnal Preferensi Hukum 2, no. 1 (2021): 122. https://doi.org/10.22225/jph.2.1.3056.119-124.

Nugroho, Hibnu. "Efektivitas Fungsi Koordinasi Dan Supervisi Dalam Penyidikan Tindak Pidana Korupsi Oleh Komisi Pemberantasan Korupsi." Jurnal Dinamika Hukum 13, no. 3 (September 2013): 392-401.

Pinilih, Sekar Anggun Gading. "Politik Hukum Kedudukan Kpk Sebagai Lembaga Pemberantasan Korupsi Di Indonesia." Jurnal Hukum Progresif 8, no. 1 (2020): 23. https://doi.org/10.14710/hp.8.1.15-27. 
Satrio, Ndaru, and Sintong Arion Hutapea. "Reformulasi Rekrutmen Penyelidik Dan Penyidik Komisi Pemberantasan Korupsi Perspektif Cita Hukum Pancasila.” Res Judicata 4, no. 2 (2021): 186-99.

Schutte, Sofie Arjon. "From Global Paradigms to Grounded Policies: Local Socio-Cognitive Constructions of International Development Policies and Implications for Development Management." Journal Public Administration and Development 32, no. April (2012): 3848. https://doi.org/10.1002/pad.

Setiadi, Wicipto. "Korupsi Di Indonesia (Penyebab, Bahaya, Hambatan, Dan Upaya Pemberantasan, Serta Regulasi",,." Jurnal Legislasi Indonesia 15, no. 3 (2018): 249-62.

Shandy Utama, Andrew. "Independensi Pengawasan Terhadap Bank Badan Usaha Milik Negara (Bumn) Dalam Sistem Hukum Nasional Di Indonesia.” Soumatera Law Review 1, no. 1 (2018): 10. https://doi.org/10.22216/soumlaw.v1i1.3312.

Terisno, Prisilia Anggraini Evelyn, and Yuliana Angela. "Penjatuhan Dua Putusan Perkara Pidana Dalam Suatu Objek Perkara Yang Sama (Kajian Putusan Nomor 2135 K/Pid.Sus/2016)." Indonesian Journal of Criminal Law (IJoCL) 1, no. 1 (2019): 105-37. https://doi.org/10.31960/ijocl.v1i1.145.

Umam, Ahmad Khoirul, Gillian Whitehouse, Brian Head, and Mohammed Adil Khan. "Addressing Corruption in Post-Soeharto Indonesia: The Role of the Corruption Eradication Commission." Journal of Contemporary Asia 50, no. 1 (2020): 125-43. https://doi.org/10.1080/00472336.2018.1552983.

Wahyuningrum, Kartika Sasi, Hari Sutra Disemadi, and Nyoman Serikat Putra Jaya. "Independensi Komisi Pemberantasan Korupsi: Benarkah Ada?" Refleksi Hukum: Jurnal Ilmu Hukum 4, no. 2 (2020): 250. https://doi.org/10.24246/jrh.2020.v4.i2.p239-258.

Warasih, Esmi. "Wewenang Komisi Pemberantasan Korupsi Dalam Penghentian Penyidikan Dan Penuntutan Perspektif Independensi,." University of Bengkulu Law Journal 5, no. 1 (2020): 41.

Yanto, Oksidelfa. "Efektifitas Putusan Pemidanaan Maksimal Bagi Pelaku Tindak Pidana Korupsi Dalam Rangka Pengentasan Kemiskinan.” Syiah Kuala Law Journal 1, no. 2 (2017): 18-36. https://doi.org/10.24815/sklj.v1i2.8471.

Yusriadi, Sy., Suhadi, and Rosdiana. "Analisis Hukum Terhadap Penegakan Hukum Perbarengan Antara Tindak Pidana Penggelapan Dengan Tindak Pidana Narkotika Di Kota Balikpapan.” Lex Suprema 2, no. 1 (2020): 131.

\section{Regulations}

Law no. 19 of 2019 amending Law No. 30 of 2002 concerning the Commission for the Eradication of Criminal Acts of Corruption 